\title{
PENGARUH PENAMBAHAN FORMALDEHID PADA PEMBUATAN UNDEGRADED PROTEIN DAN TINGKAT SUPLEMENTASINYA PADA PELET PAKAN LENGKAP TERHADAP AKTIVITAS MIKROBIA RUMEN SECARA IN VITRO
}

\section{THE EFFECT OF FORMALDEHYDE INCLUSION ON UNDEGRADED PROTEIN PROCESSING AND ITS SUPPLEMENTATION LEVEL ON COMPLETE FEED PELLET ON IN VITRO RUMEN MICROBIAL ACTIVITIES}

\author{
Bambang Suhartanto*, Ristianto Utomo, Kustantinah, I Gede Suparta Budisatria, Lies Mira Yusiati, \\ dan Budi Prasetyo Widyobroto \\ Fakultas Peternakan, Universitas Gadjah Mada, Jl. Fauna No. 3, Bulaksumur, Yogyakarta, 55281
}

\section{INTISARI}

Penelitian dilakukan untuk mengetahui pengaruh konsentrasi formaldehid pada pembuatan undegraded protein (UDP) yang digunakan untuk mensuplementasi pelet pakan lengkap terhadap aktivitas mikrobia rumen secara in vitro. Hasil sisa tanaman pertanian dan hasil samping pengolahannya digunakan untuk menyusun pelet pakan lengkap yang mengandung $12 \%$ protein kasar (PK) dan $62 \%$ total digestible nutrients (TDN). Cairan rumen untuk percobaan in vitro kecernaan bahan kering $(\mathrm{KcBK})$ dan kecernaan bahan organik $(\mathrm{KcBO})$ dan in vitro produksi gas diambil dari 2 ekor sapi Peranakan Ongole betina umur 2-3 tahun yang difistula pada bagian rumennya. Konsentrasi formaldehid 0; 0,5; 1,$0 ; 1,5 ;$ dan 2,0\% (volume/berat) digunakan untuk memproteksi bungkil kedelai pada pembuatan UDP, masing-masing adalah K-0, K-0,5, K-1,0, K-1,5, dan K-2,0. Tingkat proteksi bungkil kedelai diuji pada sampel UDP terhadap degradasi bahan kering dan organik secara in vitro. Selanjutnya UDP yang paling baik digunakan untuk mensuplementasi pelet pakan lengkap. Aktivitas mikrobia rumen dari berbagai tingkat suplementasi UDP 0; 2,5; 5,0; 7,5; dan 10\% bahan kering (berat/berat) pada pelet pakan lengkap berturut-turut adalah S-0, S-2,5, S-5,0, S-7,5, dan S-10,0 diuji secara in vitro produksi gas meliputi: produksi gas, sintesis protein mikrobia, produksi dan proporsi asam lemak volatil. Data hasil penelitian dianalisis variansi menurut Rancangan Acak Lengkap pola searah. Beda antar rerata diuji dengan Duncan's Multiple Range Test. Hasil penelitian menunjukkan KcBK (\%) bungkil kedelai tidak diproteksi K-0 lebih tinggi $(\mathrm{P}<0,05)$ dibanding $\mathrm{K}-0,5$, dan $\mathrm{K}-0,5$ lebih tinggi $(\mathrm{P}<0,05)$ dibanding $\mathrm{K}-1,0, \mathrm{~K}-1,5$ dan $\mathrm{K}-2,0$. KcBO bungkil kedelai tidak diproteksi lebih tinggi $(\mathrm{P}<0,05)$ dibanding $\mathrm{K}-0,5$, dan $\mathrm{K}-0,5$ lebih tinggi $(\mathrm{P}<0,05)$ dibanding $\mathrm{K}-1,0, \mathrm{~K}-1,5$, dan K-2,0. Perbedaan tingkat suplementasi tidak mempengaruhi produksi gas antar perlakuan pada S-0, S-2,5, S-5,0, S-7,5 dan S-10. Sintesis protein mikrobia $\mathrm{mg} / \mathrm{ml}$ cairan rumen tidak berbeda pada suplementasi UDP S-0, S-2,5, S-5,0, dan S-7,5, namun S-10 lebih rendah $(\mathrm{P}<0,05) \quad 0,273 \mathrm{mg} / \mathrm{ml}$. Tingkat suplementasi UDP tidak mempengaruhi konsentrasi asam lemak volatil total (mmol). Proporsi asam asetat $\mathrm{S}-0$ lebih rendah $(\mathrm{P}<0,05)$ dibanding $\mathrm{S}-5,0$ dan $\mathrm{S}-7,5$, tetapi proporsi asam propionat $\mathrm{S}-0$ lebih tinggi $(\mathrm{P}<0,05)$ dibanding $\mathrm{S}-5,0, \mathrm{~S}-7,5$, dan $\mathrm{S}-10,0$. Dapat disimpulkan bahwa penggunaan formaldehid pada tingkat $1 \%$ lebih baik dalam pembuatan UDP. Tingkat suplementasi UDP pada pelet pakan lengkap sampai 7,5\% tanpa mempengaruhi aktivitas mikrobia rumen.

(Kata kunci: Pelet pakan lengkap, Konsentrasi formaldehid, Undegraded protein, Tingkat suplementasi, Aktivitas mikrobia rumen)

\section{ABSTRACT}

The study was conducted to determine the effect of formaldehyde supplementation on undegraded protein (UDP) processing which will be used to supplement complete feed pellet on in vitro rumen microbial activities. Agriculture crop residues and by-product processing were used to make the complete feed pellet, containing $12 \%$ of crude protein $(C P)$ and $62 \%$ of total digestible nutrients (TDN). Rumen fluid for in vitro dry (IVDMD) and organic matter digestibility (IVOMD) and in vitro gas production was collected from 2 rumen fistulated Ongole Crossbred cows aged 2-3 years. The 0, 0.5, 1.0, 1.5 and 2.0\% (volume/weight) formaldehyde concentrations were applied for making the $U D P$, namely: $K-0, K-0.5, K-1.0, K-1.5$ and $K-2.5$ respectively. The protection levels of soybean meal in UDP processing were tested on in vitro dry and organic matter degradability. The best UDP was used to supplement complete feed pellets at levels of 0, 2.5, 5.0, 7.5 and 10.0\% dry matter (v/w) e.g. S-0, S-2.5, S-5.0, S-7.5 and S-10 and subjected to in-vitro gas production to measure rumen microbial activity through gas production, microbial protein synthesis and volatile fatty acid production and proportions. Data were subjected to Oneway ANOVA using Completely Randomized Design. The differences found between mean were tested by Duncan's Multiple Range Test. Results showed that IVDMD of unprotected soybean meal $(K-0)$ was significantly higher $(P<0.05)$ than $K-0.5$, and the K-0.5 was higher $(P<0.05)$ compared to K-1.0, K-1.5 and K-2.0. IVDMD of unprotected soybean meal was higher $(P<0.05)$ than

\footnotetext{
* Korespondensi (corresponding author):

Telp.+62 8157810 1333, E-mail: bamsuhar@ugm.ac.id
} 
$K-0.5$ as well. $K-0.5$ was higher $(P<0.05)$ than $K-1.0, K-1.5$ and $K-2.0$. The supplementation did not influence gas production and microbial protein synthesis on S-0, S-2.5, S-5.0, S-7.5 and S-10.0, except for S-10.0 which was significantly lower $(P<0.05)$ than other treatments. The level of UDP supplementation did not affect volatile fatty acid concentration. The proportion of acetic acid S-O was significantly lower $(P<0.05)$ than $S-5.0$ and $S-7.5$, but the proportion of propionic acid $S-0$ was significantly higher $(P<0.05)$ than $S-5.0, S-7.5$ and $S-10.0$. It can be concluded that the use of formaldehyde at $1 \%$ level of supplementation is more suitable for making the UDP. The supplementation of the UDP should up to $7.5 \%$ in complete feed pellet did not influence rumen microbial activities.

(Keywords: Complete feed pellets, Formaldehyde concentration, Undegraded protein, Supplementation level, Rumen microbial activity)

\section{Pendahuluan}

Ternak ruminansia mempunyai saluran pencernaan yang sangat komplek sehingga dalam memenuhi kebutuhan proteinnya memerlukan strategi khusus. Pemberian pakan secara konvensional tidak efisien dan cenderung boros karena sebagian besar pakan sumber protein (sekitar $60 \%$ ) terdegradasi menjadi amonia di dalam rumen (Wina dan Abdurohman, 2005). Beberapa strategi telah dikembangkan untuk meningkatkan efisiensi penyediaan protein diantaranya adalah dengan melindungi protein pakan dari degradasi mikrobia rumen (Orskov, 1982). Perlindungan protein dari degradasi mikrobia rumen dimaksudkan untuk meningkatkan jumlah protein yang masuk ke dalam saluran pencernaan bagian belakang (annal) yakni intestinum. Protein jenis ini sering disebut dengan "protein lolos cerna rumen" (Wina dan Abdurohman, 2005), "rumen undegraded protein" (Boucher et al., 2009), dan by pass protein (Orskov, 1982).

Pada budidaya ternak ruminansia, penyediaan pakan hijauan pada musim kemarau sangat terbatas. Tongkol atau janggel jagung adalah hasil samping tanaman jagung cukup melimpah pada musim kemarau sehingga dapat dimanfaatkan sebagai pakan sumber serat pengganti hijauan bagi ternak ruminansia. Tongkol jagung mengandung 5,62\% protein kasar (PK) dan energi dalam bentuk total digestible nutrients (TDN) 53,07\% (Wahyono dan Hardianto, 2004), 2,1\% PK, dan 57,8\% bahan ekstrak tanpa nitrogen (BETN), dan 36,5\% serat kasar (Gohl, 1975). Selain kandungan nutrisinya yang rendah, pemanfaatan tongkol jagung mengalami kendala yaitu dalam pemberiannya harus digiling terlebih dahulu. Pakan yang disusun dari hasil sisa tanaman pertanian seperti tongkol jagung memerlukan formulasi yang tepat dan suplementasi pakan sumber energi dan protein (Utomo, 2005).

Bungkil kedelai merupakan salah satu pakan konsentrat sumber protein yang berkualitas tinggi tetapi pada ternak ruminansia sebagian besar (80-90\%) protein tersebut terdegradasi di dalam rumen (Widyobroto et al., 1998). Penggunaan formaldehid cukup efektif untuk menurunkan degradasi bungkil kedelai di dalam rumen. Proteksi bungkil kedelai dengan $1 \%$ formaldehid terbukti secara signifikan menurunkan degradasi protein di dalam rumen sebesar 14,81\% (Widyobroto et al., 1997). Formaldehid (HCHO) dalam bentuk aslinya merupakan gas yang tidak berwarna, terdapat dalam tubuh sebagai senyawa intermediet (antara) dari produksi sejumlah senyawa kimia penting (seperti asam amino, lipid), sangat larut dalam air dan semua pelarut organik. Formaldehid yang terhirup melalui saluran pernafasan dapat menyebabkan kanker pada manusia. Formaldehid dalam bentuk larutan (formalin) dapat menimbulkan alergi dan iritasi pada kulit dan saluran pencernaan pada pemberian melalui oral (Muller, 2002).

Selain menggunakan formaldehid untuk memproteksi bungkil kedelai dapat pula dilakukan dengan senyawa kimia lignosulfonat dan pemanasan. Penggunaan lignosulfonat dan formaldehid untuk memproteksi bungkil kedelai lebih mudah, murah dan lebih baik dibandingkan metode perlakuan pemanasan, karena perlakuan kimia tidak menimbulkan "reaksi pencoklatan" (browning reaction) yang dapat menyebabkan berkurangnya ketersediaan asam amino (iso-leusine, leusine fenilalanin dan valin) dalam intestinum (Borucki-Castro et al., 2007).

Pakan di dalam rumen akan difermentasikan oleh aktivitas mikrobia (bakteri, protozoa, dan kapang/fungi). Hidrolisis karbohidrat menghasilkan volatile fatty acids (VFA) yaitu asam asetat $\left(\mathrm{C}_{2}\right)$, propionat $\left(\mathrm{C}_{3}\right)$, isobutirat $\left(\mathrm{IC}_{4}\right)$, butirat $\left(\mathrm{C}_{4}\right)$, isovalerat $\left(\mathrm{IC}_{5}\right)$ dan valerat $\left(\mathrm{C}_{5}\right)$ dan digunakan sebagai sumber energi utama bagi ternak ruminansia maupun mikrobia rumen itu sendiri (Czerkawski, 1978; Mc Donald et al., 1988). Dilaporkan bahwa 66-75\% energi bagi ternak ruminansia diperoleh dari VFA (INRA, 1980). Proporsi dan konsentrasi VFA bervariasi tergantung pada jenis pakan, imbangan hijauan dan konsentrat, dan distribusinya (Van Soest, 1994).

Protein pakan akan didegradasi menjadi amonia oleh mikrobia di dalam rumen, sedangkan protein pakan yang tidak terdegradasi akan menuju intestinum dan mengalami pencernaan secara 
enzimatis. Mikrobia rumen dapat mengkonversi protein kualitas rendah menjadi protein berkualitas tinggi, tetapi dapat pula merombak protein pakan berkualitas tinggi menjadi amonia (Van Soest, 1994), dan menyebabkan hilangnya energi selama proses fermentasi berupa gas $\left(\mathrm{CO}_{2}\right.$ dan $\left.\mathrm{CH}_{4}\right)$ sehingga akan menurunkan nilai biologis protein pakan yang berkualitas tinggi (Cheeke, 2005).

Penelitian ini dilakukan untuk mengetahui pengaruh konsentrasi formaldehid pada pembuatan undegraded protein (UDP) dari bungkil kedelai dan penggunaannya pada suplementasi pelet pakan lengkap dengan bahan baku hasil samping tanaman pertanian terhadap aktivitas mikrobia rumen secara in vitro.

\section{Materi dan Metode}

\section{Materi}

Bungkil kedelai untuk pembuatan UDP diperoleh dari PT. Multiphala Agrinusa, JAFPA COMFEED, Sragen Jawa-Tengah. Formaldehid teknis dibeli dari distributor bahan kimia di Yogyakarta berupa formalin (37\% formaldehid). Dua ekor sapi Peranakan Ongole (PO) betina umur 2-3 tahun yang difistula pada bagian rumennya digunakan sebagai donor cairan rumen pada percobaan in vitro kecernaan bahan kering dan bahan organik (Tilley dan Terry, 1963) dan in vitro produksi gas dari Hohenheim Gas Test (Menke dan Steingass, 1988). Pakan lengkap (complete feed) yang digunakan berupa pelet yang disusun dari hasil sisa tanaman dan hasil ikutan pengolahan hasil pertanian dengan kandungan PK $12,10 \%$ dan TDN 63,46\% (Tabel 1).

\section{Metode}

Pembuatan undegraded protein. Perlakuan 5 konsentrasi (K) formaldehid yaitu $0,0,5,1,0,1,5$, dan 2,0\% (\% bahan kering) digunakan untuk memproteksi protein bungkil kedelai pada pembuatan UDP (volume/berat) berturut-turut K-0, $\mathrm{K}-0,5$, K-1,0, K-1,5, dan K-2,0. Sesuai dengan konsentrasi perlakuan, larutan formalin (37\% formaldehid) disemprotkan secara merata pada bungkil kedelai, diperam semalam (sekitar 12 jam) kemudian dikering-anginkan sehari dan dijemur di bawah sinar matahari selama 2 hari sampai kering (kadar air 11-15\%). Untuk menguji tingkat proteksi bungkil kedelai, maka sampel bungkil kedelai yang telah diproteksi dari berbagai konsentrasi formaldehid diukur degradasi atau kehilangan bahan kering dan bahan organik secara in vitro dengan metode kecernaan in vitro satu tingkat dari Tilley dan Terry (1963).

Suplementasi UDP pada pelet pakan lengkap. Pelet pakan lengkap (complete feed) disusun dengan mempertimbangkan keseimbangan degradasi bahan organik (Dt-BO) dan protein kasar (Dt-PK) di dalam rumen, untuk memenuhi kebutuhan sapi potong penggemukan (fattening) dengan asumsi kenaikan berat badan $0,75 \mathrm{~kg} / \mathrm{hari}$ mengandung $12 \%$ protein kasar dan $62 \%$ TDN (Kearl, 1982). Bahan pakan dari Tabel 1 digiling kemudian dicampur menjadi pakan lengkap dan dibuat pelet ukuran $0,8-1,0 \mathrm{~cm}$ diameter dan 1,5-3 cm panjang menggunakan mesin pembuat pelet pakan ternak (pelletizer) milik UPT BPPT Kimia LIPI di Stasiun Gunungsempu, Bantul, Yogyakarta.

Undegraded protein terbaik dari hasil penelitian tingkat konsentrasi formaldehid (proteksi $1 \%$ formaldehid) digunakan untuk suplementasi (S) pelet pakan lengkap dengan tingkat $0,2,5,5,0,7,5$, dan $10,0 \%$ (berat/berat) berturut-turut yaitu S-0, S2,5, S-5,0, S-7,5, dan S-10,0. Produksi gas untuk menduga kecernaan in vitro diukur menggunakan metode Hohenheim Gas Test (Menke dan Steingass, 1988 cit. Yusiati et al., 2007). Berat biomassa mikrobia dalam cairan rumen diperkirakan dengan mengukur kadar protein mikrobia dilakukan menurut metode Lowry melalui metode spektrofotometri dari Plumer (1988). Total produksi asam lemak volatil dan proporsinya (asetat, propionat dan butirat) dalam cairan rumen, diukur menurut metode Jouany (1982) menggunakan chromatografi gas.

\section{Analisis data}

Data hasil penelitian dianalisis statistik menggunakan analisis variansi menurut Rancangan Acak Lengkap pola searah dan beda antar rerata diuji lanjut dengan uji Duncan's Multiple Range Test (Steel dan Torrie, 1980).

\section{Hasil dan Pembahasan}

\section{Kecernaan in vitro undegraded protein}

Hasil penelitian menunjukkan bahwa penggunaan formaldehid untuk memproteksi bungkil kedelai pada pembuatan UDP menurunkan $(\mathrm{P}<0,05)$ kecernaan bahan kering in vitro satu tahap (Tabel 2). Kecernaan bahan kering in vitro bungkil kedelai yang diproteksi dengan tingkat konsentrasi formaldehid K-0,5 $(52,26 \%)$ lebih rendah $(\mathrm{P}<0,05)$ dibandingkan dengan yang tidak diproteksi K-0 $(89,88 \%)$, dan tingkat $\mathrm{K}-1,0,(35,26 \%), \mathrm{K}-1,5$ $(34,50 \%)$, dan K-2,0 (37,13\%) lebih rendah $(\mathrm{P}<0,05)$ dibanding K-0,5. Tidak terdapat perbedaan antara K-1,0, K-1,5, dan K-2,0.

Degradasi bahan organik bungkil kedelai yang diproteksi dengan formaldehid lebih rendah $(\mathrm{P}<0,05)$ dibandingkan dengan yang tidak diproteksi (Tabel 2). Degradasi bahan organik in vitro bungkil kedelai pada K-0,5 (49,38\%) lebih 
Tabel 1. Komposisi bahan pakan penyusun pelet pakan lengkap (\%BK) (ingredients of complete feed pellet $(\% D M))$

\begin{tabular}{|c|c|c|c|c|c|}
\hline Bahan pakan (feed stuff) & $\begin{array}{c}\text { Dt-BO }(\%) \\
(D t-O M(\%))^{1}\end{array}$ & $\begin{array}{l}\text { Dt-PK }(\%) \\
(D t-C P(\%))^{1}\end{array}$ & $\begin{array}{l}\text { Komposisi (\%) } \\
\text { (ingredient (\%)) }\end{array}$ & $\begin{array}{l}\text { PK }(\%) \\
(C P(\%))\end{array}$ & $\begin{array}{l}\text { TDN } \\
(\%)\end{array}$ \\
\hline $\begin{array}{l}\text { Tongkol jagung giling (corn-cob } \\
\text { grinded) }\end{array}$ & 23,76 & 27,27 & 34,95 & 1,40 & 13,63 \\
\hline Dedak halus (rice bran) & 54,80 & 78,10 & 10,75 & 1,48 & 7,30 \\
\hline Onggok (cassava pomace) & 74,60 & 80,10 & 15,15 & 0,39 & 12,65 \\
\hline Tepung gaplek (dried cassava) & 93,10 & 85,90 & 21,00 & 0,69 & 18,90 \\
\hline Bungkil biji kapok (kapok seed meal) & 49,30 & 77,70 & 2,50 & 0,79 & 1,85 \\
\hline Bungkil kedelai (soybean meal) & 62,62 & 60,49 & 6,45 & 3,10 & 5,03 \\
\hline Bungkil kelapa (coprah meal) & 94,40 & 76,15 & 4,00 & 0,65 & 2,19 \\
\hline Molases (molasses) & 95,00 & 95,00 & 3,00 & 0,17 & 1,64 \\
\hline Urea & 100,00 & 100,00 & 1,20 & 3,42 & - \\
\hline Mineral Mix (mineral mixed) & & & 0,30 & - & \\
\hline Garam (salt) & & & 0,40 & & \\
\hline Perekat (binder) & & & 0,30 & 0,01 & 0,27 \\
\hline Total & & & 100,00 & 12,10 & 63,46 \\
\hline
\end{tabular}

${ }^{1}$ Sumber : Widyobroto et al. (1998).

Dt-BO: degradability bahan organik waktu t (Dt-OM: degradability of organic matter at t time).

Dt-PK: degradability protein kasar waktu $\mathrm{t}$ (Dt-CP: degradability of crude protein at t time).

PK: protein kasar (CP: crude protein)

TDN: total digestible nutrients.

Tabel 2. Degradasi bahan kering dan organik (\%BK) in vitro satu tahap bungkil kedelai terproteksi berbagai konsentrasi formaldehid (one-stage in-vitro dry and organic matter degradability of soybean meal protected various concentrations of formaldehyde)

\begin{tabular}{cccccc}
\hline \hline \multirow{2}{*}{$\begin{array}{c}\text { Kecernaan } \text { in vitro }(\%) \\
\text { (in vitro degradability }(\%))\end{array}$} & \multicolumn{4}{c}{ Konsentrasi (K) formaldehid (\%) (concentration of formaldehyde (\%)) } \\
\cline { 2 - 5 } & $\mathrm{K}-0$ & $\mathrm{~K}-0,5$ & $\mathrm{~K}-1,0$ & $\mathrm{~K}-1,5$ & $\mathrm{~K}-2,0$ \\
\hline Bahan kering $($ dry matter) & $89,88 \pm 5,15^{\mathrm{c}}$ & $52,26 \pm 3,23^{\mathrm{b}}$ & $35,26 \pm 2,54^{\mathrm{a}}$ & $34,50 \pm 4,03^{\mathrm{a}}$ & $37,13 \pm 3,03^{\mathrm{a}}$ \\
Bahan organik (organic matter) & $84,96 \pm 4,80^{\mathrm{c}}$ & $49,38 \pm 3,87^{\mathrm{b}}$ & $33,96 \pm 2,32^{\mathrm{a}}$ & $33,36 \pm 3,96^{\mathrm{a}}$ & $36,41 \pm 2,88^{\mathrm{a}}$ \\
\hline a,b,c & Superskrip yang berbeda pada baris yang sama menunjukkan perbedaan yang nyata $(\mathrm{P}<0,05)($ different \\
superscripts at the same row indicate significant differences $(P<0.05))$. & &
\end{tabular}

rendah $(\mathrm{P}<0,05)$ dibandingkan dengan yang tidak diproteksi (K-0) yaitu 84,96\%, dan K-1,0, K-1,5 dan K-2 masing-masing adalah 33,96, 33,36, dan $36,41 \%$ lebih rendah $(\mathrm{P}<0,05)$ dibanding $\mathrm{K}-0,5$, namun tidak terdapat perbedaan antara K-1,0, K-1,5, dan K-2,0. Hasil ini hampir sama dengan yang dilaporkan Mathieu dan Jouany (1993) bahwa proteksi bungkil kedelai dengan tanin pada konsentrasi $0,0,2$, dan $1,1 \%$ bahan kering menurunkan kecernaan nitrogen secara in vitro.

Hasil penelitian ini menunjukkan bahwa proteksi bungkil kedelai pada tingkat formaldehid $0,5 \%$ dapat menurunkan degradasi bahan kering dan organik. Peningkatan tingkat formaldehid dari 0,5 sampai dengan $1 \%$ masih effektif menurunkan kecernaan bungkil kedelai, namun peningkatan lebih tinggi dari $1 \%$ tidak efektif lagi menurunkan degradasi. Widyobroto et al. (1997) melaporkan bahwa proteksi bungkil kedelai dengan $1 \%$ formaldehid cukup efektif terhadap degradasi mikrobia dalam rumen. Bungkil kedelai dengan formaldehid membentuk ikatan protein-formaldehid yang stabil pada $\mathrm{pH}$ netral, tetapi bersifat labil pada $\mathrm{pH}$ asam. Cairan rumen bersifat netral sehingga ikatan tersebut di atas stabil terhadap hidrolisis enzim yang dihasilkan oleh mikroorganisme dalam rumen. Penurunan degradasi bungkil kedelai dalam rumen disebabkan terjadinya reaksi irreversibel antara protein bungkil kedelai pada gugus asam amino dengan formaldehid yang tidak larut dalam cairan rumen ( $\mathrm{pH}$ netral).

Dari hasil degradasi bahan kering dan organik di atas maka proteksi bungkil kedelai sebagai pakan ternak ruminansia cukup dilakukan 
dengan $1 \%$ formaldehid saja. Konsentrasi $1 \%$ cukup efektif melindungi bungkil kedelai dari degradasi mikrobia dalam rumen. Peningkatan konsentrasi formaldehid tidak perlu dilakukan mengingat formaldehid adalah bahan kimia berbahaya yang apabila terdapat dalam jumlah lebih besar dapat menurunkan aktivitas mikrobia dalam rumen dan mencemari lingkungan. European Food Safety Authority menyatakan bahwa formaldehid dalam pakan ternak pada konsentrasi $68-680$ ppm secara cepat akan diabsorbsi dalam saluran pencernaan dan bergabung dengan pool formaldehid dalam tubuh. Formaldehid tersebut dengan cepat akan dioksidasi menjadi asam format kemudian menjadi $\mathrm{CO}_{2}$ dan air. Lebih lanjut dinyatakan bahwa penggunaan formaldehid dalam pakan ternak tidak akan terakumulasi dan menimbulkan bahaya lingkungan (Adiveter, 2014).

\section{Aktivitas mikrobia rumen}

Hasil pengukuran secara in vitro produksi gas dan sintesis protein mikrobia dalam cairan rumen dari pakan lengkap dengan berbagai tingkat suplementasi UDP tersaji pada Tabel 3.

Hasil penelitian menunjukkan bahwa tingkat suplementasi UDP tidak mempengaruhi aktivitas mikrobia yang diukur melalui produksi gas secara in vitro (Tabel 3). Apabila bungkil kedelai tidak diproteksi, maka adanya bungkil kedelai tersebut akan meningkatkan produksi gas. Demikian pula adanya formaldehid dalam bungkil kedelai juga tidak berpengaruh terhadap produksi gas. Dalam UDP dari bungkil kedelai yang diproteksi dengan formaldehid maka sebagian formaldehid terikat dalam ikatan protein-formaldehid yang tidak larut dan sebagian yang lain tidak terikat akan dibebaskan dalam cairan rumen. Hal ini dapat dibuktikan dengan analisis pendahuluan yang dilakukan pada bungkil kedelai yang diproteksi dengan 1\% formaldehid (UDP) dalam air 1:10 (berat/volume) terdeteksi formaldehid dalam air sekitar $80 \mathrm{ppm}$. Dengan demikian semakin tinggi tingkat suplementasi yang diberikan maka akan semakin tinggi pula formaldehid yang akan dibebaskan dalam cairan rumen, sehingga akan menghambat aktivitas mikroorganisme dalam rumen. Peningkatan suplementasi UDP yang berarti pula semakin banyak formaldehid yang dibebaskan dalam rumen, namun dalam penelitian ini tidak menurunkan aktivitas mikrobia rumen secara signifikan, hanya menunjukkan sedikit penurunan sampai dengan tingkat $2,5 \%$.

Tidak adanya (tidak terdeteksi) kandungan formaldehid dalam cairan rumen pada akhir percobaan in vitro produksi gas membuktikan bahwa mikroorganisme rumen mampu mengeliminasi formaldehid dari cairan rumen. Kandungan formaldehid dalam pakan ternak kurang dari 680 ppm akan diabsorbsi dalam saluran pencernaan dan dimetabolismekan menjadi $\mathrm{CO}_{2}$ dan dieliminasi melalui saluran pernafasan (Adiveter, 2014).

Sintesis protein mikrobia yang terdapat dalam cairan rumen dapat diprediksi dengan mengukur berat protein dari isolat mikrobia. Hasil penetapan berat protein mikrobia tersaji pada Tabel 3. Berat protein mikrobia $\mathrm{mg}$ protein $/ \mathrm{ml}$ cairan rumen in vitro dari pakan lengkap yang disuplementasi bungkil kedelai terproteksi formaldehid pada $\mathrm{S}-0$, S-2,5, S-5,0, S-7,5, dan S-10,0 berturut-turut adalah $0,321 \mathrm{mg}, 0327 \mathrm{mg}, 0,310 \mathrm{mg}, 0,308 \mathrm{mg}$, dan $0,273 \mathrm{mg}$ protein/ml. Peningkatan suplementasi sampai dengan tingkat $7,5 \%$ berpengaruh tidak nyata terhadap sintesis protein mikrobia dalam cairan rumen, tetapi pada tingkat $10,0 \%$ menurunkan $(\mathrm{P}<0,05)$ sintesis protein mikrobia. Hal ini membuktikan bahwa semakin tinggi suplementasi UDP menyebabkan jumlah formaldehid yang

Tabel 3. Produksi gas in vitro dan sintesis protein mikrobia cairan rumen pada berbagai tingkat suplementasi undegraded protein (UDP) pada pelet pakan lengkap (in vitro gas production and number of microbial protein synthesis in rumen fluid on various levels of undegraded protein (UDP) suplementation on complete feed)

\begin{tabular}{|c|c|c|c|c|c|}
\hline & \multicolumn{5}{|c|}{$\begin{array}{l}\text { Suplementasi UDP }(\% \mathrm{BK}) \text { pada pelet pakan lengkap } \\
(\text { UDP supplementation }(\% D M) \text { on pellet of complete feed })\end{array}$} \\
\hline & $S-0$ & $S-2,5$ & $S-5,0$ & S-7,5 & $S-10,0$ \\
\hline $\begin{array}{l}\text { Produksi gas }(\mathrm{ml} / 300 \mathrm{mg})(\text { gas } \\
\text { production }(\mathrm{ml} / 300 \mathrm{mg}))^{\mathrm{ns}}\end{array}$ & $82,67 \pm 1,22$ & $81,50 \pm 0,67$ & $79,83 \pm 1,56$ & $77,33 \pm 1,11$ & $76,67 \pm 4,44$ \\
\hline $\begin{array}{l}\text { Sintesis protein mikrobia }(\mathrm{mg} / \mathrm{ml}) \\
\text { (microbial protein synthesis } \\
(\mathrm{mg} / \mathrm{ml}) \text { ) }\end{array}$ & $0,321 \pm 0,02^{\mathrm{a}}$ & $0,327 \pm 0,01^{\mathrm{a}}$ & $0,310 \pm 0,01^{\mathrm{a}}$ & $0,308 \pm 0,02^{\mathrm{a}}$ & $0,273 \pm 0,01^{\mathrm{b}}$ \\
\hline
\end{tabular}


terlarut semakin banyak sehingga akan menghambat aktivitas dan menurunkan sintesis protein mikrobia dalam rumen. Pakan lengkap disusun untuk memenuhi kebutuhan sumber energi dan protein bagi perkembangan mikrobia dalam rumen dan ternak inangnya, sehingga pakan lengkap yang mendapat suplementasi bungkil kedelai terproteksi maka ketersediaan substrat dan adanya formaldehid akan menurunkan aktivitas mikrobia. Suplementasi sampai dengan $7,5 \%$ belum berpengaruh negatif terhadap aktivitas mikrobia sehingga populasi dan sintesis protein mikrobia rumen tidak terpengaruh.

\section{Asam lemak volatil}

Konsentrasi asam lemak volatil total. Konsentrasi asam lemak volatil atau VFA total yang ditetapkan dari hasil degradasi in vitro tersaji pada Tabel 4.

Konsentrasi asam lemak volatil total (mmol) dalam cairan rumen hasil degradasi pakan lengkap pada suplementasi UDP 0, 2,5, 5,0, 7,5 dan 10,0\% berturut-turut adalah 100,82, 94,12, 87,02, 106,32 dan 88,33 $\mathrm{mmol} / \mathrm{ml}$ (Tabel 4). Hasil analisis statistik menunjukkan perbedaan tingkat suplementasi UDP pada pakan lengkap tidak mempengaruhi konsentrasi asam lemak volatil total. Bahan pakan yang masuk ke dalam rumen akan mengalami fermentasi oleh populasi mikroorganisme. Mc Donald et al. (1988) menyatakan bahwa selama proses fermentasi tersebut, karbohidrat akan dihidrolisis menjadi asam lemak volatil. Lebih dari $60 \%$ bahan organik tercerna di dalam rumen menghasilkan VFA, $\mathrm{NH}_{3}, \mathrm{CO}_{2}, \mathrm{CH}_{4}$, dan $\mathrm{H}_{2}$ (Jouany, 1991). Konsentrasi VFA bervariasi 50-80 $\mathrm{mmol} / \mathrm{ml}$ tergantung dari pakan yang diberikan. INRA (1980) melaporkan bahwa 66-75\% energi bagi ternak ruminansia diperoleh dari asam lemak volatil. Asam lemak volatil merupakan sumber energi yang penting bagi ternak ruminansia dan mikrobia dalam rumen itu sendiri. Proporsi dan konsentrasi asam lemak volatil di dalam cairan rumen bervariasi tergantung dari jenis pakan, imbangan hijauan dan konsentrat, dan distribusinya (Van Soest, 1994). Dari penelitian ini konsentrasi VFA tidak dipengaruhi oleh tingkat suplementasi UDP yang diberikan dalam bentuk bungkil kedelai terproteksi formaldehid $1 \%$. Hal ini disebabkan hanya sebagian kecil UDP yang terdegradasi, sehingga suplementasi tidak dapat meningkatkan konsentrasi VFA. Pada kenyataannya sebagian formaldehid yang digunakan untuk memproteksi bungkil kedelai larut dan masuk ke dalam cairan rumen. Efek dari adanya formaldehid tersebut akan menghambat aktivitas mikroorganisme di dalam rumen, sehingga dapat menurunkan konsentrasi VFA total. Di satu sisi suplementasi bungkil terproteksi formaldehid akan meningkatkan substrat tetapi di sisi yang lain akan menurunkan aktivitas mikroorganisme dalam rumen sehingga konsentrasi asam lemak volatil relatif sama pada berbagai tingkat suplementasi.

Proporsi asam asetat. Proporsi asam asetat dari VFA total dalam cairan rumen hasil kecernaan in vitro tersaji pada Tabel 4. Proporsi asam asetat dalam cairan rumen pada in vitro pakan lengkap yang disuplementasi bungkil kedelai terproteksi

Tabel 4. Konsentrasi dan proporsi asam lemak volatil (VFA) dalam cairan rumen pada degradasi in vitro pelet pakan lengkap pada berbagai tingkat suplementasi undegraded protein (UDP) (concentration and proportion of volatile fatty acids (VFA) in rumen fluid on in vitro degradability of complete feed pellet) in various levels of undegraded protein (UDP) supplementation)

\begin{tabular}{|c|c|c|c|c|c|}
\hline \multirow[t]{2}{*}{ Variabel (variable) } & \multicolumn{5}{|c|}{$\begin{array}{c}\text { Suplementasi UDP pada pakan lengkap (\%BK) } \\
(\text { UDP suplementation on complete feed pellet }(\% D M))\end{array}$} \\
\hline & S-0 & S-2,5 & $S-5,0$ & S-7,5 & S-10,0 \\
\hline $\begin{array}{l}\text { Konsentrasi VFA }(\mathrm{mmol}) \\
(\text { concentration of } V F A(m m o l))^{\mathrm{ns}}\end{array}$ & $100,82 \pm 4,21$ & $94,12 \pm 10,39$ & $87,02 \pm 0,24$ & $106,32 \pm 12,45$ & $88,33 \pm 21,03$ \\
\hline $\begin{array}{l}\text { Proporsi asam asetat }(\%) \\
\text { (proportion of acetic acid }(\%) \text { ) }\end{array}$ & $70,58 \pm 0,11^{\mathrm{a}}$ & $73,72 \pm 1,51^{\mathrm{ab}}$ & $77,50 \pm 0,75^{\mathrm{b}}$ & $75,51 \pm 1,53^{\mathrm{b}}$ & $74,21 \pm 2,51^{\mathrm{ab}}$ \\
\hline $\begin{array}{l}\text { Proporsi asam propionat }(\%) \\
\text { (proportion of propionic acid } \\
(\%) \text { ) }\end{array}$ & $19,16 \pm 0,05^{\mathrm{c}}$ & $17,11 \pm 0,94^{\mathrm{bc}}$ & $14,32 \pm 0,56^{\mathrm{a}}$ & $15,42 \pm 1,12^{\mathrm{ab}}$ & $15,93 \pm 1,28^{\mathrm{ab}}$ \\
\hline $\begin{array}{l}\text { Proporsi asam butirat }(\%) \\
(\text { proportion of butyric acid } \\
(\%))^{\mathrm{ns}}\end{array}$ & $10,26 \pm 0,16$ & $9,17 \pm 0,61$ & $8,18 \pm 0,19$ & $9,08 \pm 0,40$ & $9,86 \pm 1,23$ \\
\hline $\begin{array}{l}\text { Rasio asetat-propionat (acetic } \\
\text { and propionic ratio })^{\mathrm{ns}}\end{array}$ & $4,37 \pm 0,92$ & $4,33 \pm 0,32$ & $4,88 \pm 0,74$ & $4,94 \pm 0,49$ & $4,72 \pm 0,57$ \\
\hline
\end{tabular}


formaldehid (UDP) tingkat $0 \%(70,58 \%)$ lebih rendah $(\mathrm{P}<0,05)$ dibanding tingkat 5,0 dan $7,5 \%$ (77,5 dan $75,51 \%)$. Terdapat perbedaan yang tidak nyata antara tingkat suplementasi $0 \%(70,58 \%)$ dengan 2,5 dan $10,0 \%(73,72$ dan $74,21 \%)$ dan antara tingkat 5,0 dan 7,5\% dengan tingkat 2,5 dan $10 \%$ terhadap proporsi asam asetat dalam cairan rumen. Proporsi asam asetat dari hasil fermentasi pakan hijauan (pakan berserat) di dalam rumen lebih tinggi dibanding dengan pakan konsentrat, sebaliknya proporsi asam propionat lebih tinggi pada pakan konsentrat. Hasil penelitian ini menunjukkan bahwa penambahan substrat berupa bungkil kedelai terproteksi tidak menurunkan proporsi asam asetat, tetapi sebaliknya akan meningkatkannya. Hal ini membuktikan bahwa sebagian besar bungkil kedelai yang mudah larut (terdegradasi) akibat adanya proteksi ini sebagian menjadi tidak terdegradasi di dalam rumen menghasilkan asam propionat.

Proporsi asam propionat. Proporsi asam propionat dalam cairan rumen hasil kecernaan in vitro tercantum dalam Tabel 4. Proporsi asam propionat dalam cairan rumen pada in vitro pakan lengkap yang disuplementasi bungkil kedelai terproteksi formaldehid tingkat 5\% (14,32\%) lebih rendah $(\mathrm{P}<0,05)$ dibanding tingkat $0 \%(19,16 \%)$ dan $2,5 \%(17,11 \%)$. Terdapat perbedaan yang tidak nyata antara tingkat suplementasi 5,0 dengan 7,5 dan 10,0\% masing-masing yaitu 15,42 dan $15,93 \%$, dan antara tingkat 7,5 dan 10,0\% dengan tingkat $2,5 \%$ serta antara tingkat 0 dengan $2,5 \%$ terhadap proporsi asam propionat dalam cairan rumen. Proporsi asam propionat dalam rumen meningkat sesuai dengan meningkatnya proporsi pakan konsentrat (biji-bijian). Vermorel (1988) melaporkan bahwa proporsi energi yang diabsorbsi ternak dari asam asetat menurun dari 40 menjadi $25 \%$ ketika pakan hijauan kualitasnya ditingkatkan dengan suplementasi pakan konsentrat 0 sampai $60 \%$, sebaliknya proporsi energi asal asam propionat meningkat dari 13 menjadi $20 \%$. Peningkatan tingkat UDP akan meningkatkan jumlah formaldehid yang dibebaskan, dan akan melindungi degradasi bahan organik/karbohidrat mudah larut, sehingga akan menurunkan terbentuknya asam propionat.

Proporsi asam butirat. Proporsi asam butirat dalam cairan rumen hasil kecernaan in vitro tersaji pada Tabel 4. Pada tingkat suplementasi 0, 2,5, 5,0, 7,5 dan 10,0\% berturut-turut proporsi (\%) asam butirat dalam cairan rumen adalah 10,26, 9,17, $8,18,9,08$, dan 9,86\%. Hasil analisis variansi di antara tingkat suplementasi menunjukkan perbedaan yang tidak nyata.

Proporsi (\%) asam butirat $\left(\mathrm{C}_{4}\right)$ dalam cairan rumen pada in vitro pakan lengkap tidak dipengaruhi oleh tingkat suplementasi bungkil kedelai terproteksi formaldehid. Asam butirat adalah salah satu asam lemak volatil yang penting dalam cairan rumen setelah asam asetat dan propionat. Di dalam rumen $90 \%$ asam butirat dimetabolismekan menjadi benda keton selanjutnya digunakan untuk menyusun lemak atau digunakan sebagai sumber energi dalam siklus asam sitrat (Vermorel, 1988; Van Soest, 1994). Suplementasi bungkil kedelai terproteksi tidak meningkatkan proporsi asam butirat, karena sebagian besar bungkil kedelai yang disuplementasikan terproteksi yaitu degradasi bahan kering hanya 35,26\%. Hal inilah yang menyebabkan bahwa suplementasi bungkil kedelai tersebut tidak meningkatkan proporsi asam propionat bahkan sebaliknya menurunkan, dan tidak mempengaruhi proporsi asam butirat. Proporsi asam butirat akan meningkat jika dalam pakan terdapat sumber karbohidrat mudah larut seperti bit gula dan laktoserum serta protein asal hijauan legum Trifolium repens (Jarrige, 1988).

Rasio asam asetat propionat. Rasio asam asetat dengan propionat $\left(\mathrm{C}_{2} / \mathrm{C}_{3}\right)$ cairan rumen hasil kecernaan in vitro tercantum dalam Tabel 4 , pada tingkat suplementasi UDP $0,2,5,5,0,7,5$ dan $10,0 \%$ berturut-turut adalah $4,37,4,33,4,88,4,94$, dan $4,72 \%$. Hasil analisis statistik menunjukkan bahwa tingkat suplementasi UDP pada pakan lengkap tidak mempengaruhi rasio asam asetat dan propionat. Proporsi asam asetat dan propionat dipengaruhi oleh tingkat suplementasi bungkil kedelai terproteksi, tetapi rasio keduanya tidak dipengaruhi. Biasanya pada pakan yang disuplementasi dengan konsentrat seperti halnya bungkil kedelai rasio asetat-propionat turun, akibat meningkatnya proporsi asam propionat (Vermorel, 1988). Hal ini menunjukkan bahwa proteksi bungkil kedelai dengan formaldehid cukup berhasil melindungi pakan sumber protein dari degradasi mikrobia rumen, sehingga diharapkan dapat digunakan langsung oleh ternak inangnya di dalam intestinum. Peningkatan suplementasi UDP pada pakan tetapi rasio $\mathrm{C}_{2}$ dan $\mathrm{C}_{3}$ tidak berubah membuktikan bahwa bungkil kedelai tidak tercerna di dalam rumen sehingga tidak mempengaruhi penyediaan substrat bagi mikrobia yang akan mempengaruhi produksi VFA.

\section{Kesimpulan dan Saran}

\section{Kesimpulan}

Penggunaan $1 \%$ formaldehid pada pembuatan UDP dari bungkil kedelai mampu melindungi protein terhadap degradasi dalam rumen yang dicerminkan dari penurunan degradasi bahan kering dan organiknya. Bungkil kedelai yang diproteksi 
dengan $1 \%$ formaldehid dari bahan kering mampu melindungi pakan sumber protein dari degradasi mikrobia dalam rumen yang ditunjukkan dari aktivitas fermentasi dalam rumen yaitu produksi gas, konsentrasi VFA total, proporsi asam butirat dan rasio asetat-propionat yang tidak terpengaruh suplementasi UDP. Suplementasi UDP sampai dengan $7,5 \%$ bahan kering pada pelet pakan lengkap tidak mempengaruhi sintesis protein mikrobia rumen, namun suplementasi UDP sampai dengan 5\% mulai menurunkan proporsi asam propionat tetapi meningkatkan proporsi asam asetat dalam cairan rumen.

\section{Saran}

Sebaiknya suplementasi UDP berupa bungkil kedelai terproteksi formaldehid pada pelet pakan lengkap diberikan pada tingkat kurang dari 5\% bahan kering.

\section{Daftar Pustaka}

Adiveter, L. 2014. Scientific opinion on the safety and efficacy of formaldehyde for all animal species. In: European Food Safety Authority (EFSA) Panel on Additives and Products or Substances Used in Animal Feed (FEEDAP) Parma, Italy. EFSA Journal 12: 3562.

Borucki-Castro, S. I., L. E. Phillip, H. Lapierre, P. W. Jardon and R. Berthiaumet. 2007. Ruminal degradability and intestinal digestibility of protein and amino acids in treated soybean meal products. J. Dairy Sci. 90: 810-822.

Boucher, S. E., S. Calsamiglia, C. M. Parsons, H. H. Stein, M. D. Stern, P. S. Erickson, P. L. Utterback and C. G. Schwab. 2009. Intestinal digestibility of amino acids in rumenundegraded protein estimated using a precision-fed cecectomized rooster bioassay: II. Distillers dried grains with solubles and fish meal. J. Dairy Sci. 92: 6056-6067.

Cheeke. 2005. Applied Animal Nutrition. Feed and Feeding. $3^{\text {rd }}$ ed. Pearson Prentice Hall. New Jersey.

Czerkawski, J. W. 1978. Reassesment of efficiency of synthesis of microbial matter in the rumen. J. Dairy Sci. 61: 1261-1273.

Gohl, B. 1975. Feeds information summaries and nutritive values. In: Tropical Feeds. FAO, The United Nations. Rome.

INRA. 1980. Alimentation des Ruminants. R. Jarrige (ed). INRA-Paris. Paris.

Jarrige, R. 1988. Ingestion et digestion des aliments. Dans: Alimentation des Bovins, Ovins et Caprins. R. Jarrige (ed). INRA-Paris. Paris.
Jouany, J. P. 1982. Volatile fatty acid and alcohol determination in digestive contents, silages juices, bacterial culture and aerobic fermentor contents. Sci. des Aliments. 2: 131-144.

Jouany, J. P. 1991. Defaunation of the rumen. In: Rumen Microbial Metabolism and Ruminant Digestion. INRA. Paris.

Kearl, L. C. 1982. Nutrient Requirement of Ruminants in Developing Countries. IFI. Utah Agriculture Exp. Station. Utah State University. Logan. Utah.

Mathieu, F. dan J. P. Jouany 1993. Effect of chestnut tannin on the fermentability of soybean meal nitrogen in the rumen. Ann. Zootech. 42: 127.

Mc Donald P., R. A. Edwards and J. F. D. Greenhalgh. 1988. Animal Nutrition. Fourth Ed. Longman Scientific \& Technical. John Welly and Sons Inc. New York.

Menke, K. H. and H. Steingass. 1988. Estimation of the energetic feed value obtained from chemical analysis and in vitro gas production using rumen fluid. Anim. Res. Dev. 28: 7-55.

Muller, G. 2002. A field study into the nutritional intake of horses fed grass silage or hay as roughage including factors influencing faecal consistency. Ph.D. Disertations. Tierarztliche Hochschule Hannover, Hannover.

Ørskov, E. R. 1982. Protein Nutrition in Ruminants. First Published. Academic Press Limited. London.

Plumer, D. T. 1988. An Introduction to Practical Biochemistry. $3^{\text {rd }}$ ed. McGraw Hill Ltd. New Delhi.

Steel, R. G. D. and J. H. Torrie. 1980. Principles and Procedure of Statistic. Mc Graw-Hill Co. New York.

Tilley, J. M. and R. A. Terry. 1963. A two-stage technique for the in vitro digestion of forage crops. J. Br. Grassl. Soc. 18: 104-111.

Utomo, R. 2005. Suplementasi campuran dedak halus dan tepung daun lamtoro pada jerami padi sebagai pakan basal terhadap sintesis protein mikrobia rumen sapi Peranakan Ongole. Prosiding Seminar Nasional AINI V. Pengembangan Nutrisi dan Bioteknologi Pakan Sebagai Pendorong Agroindustri di Bidang Peternakan. Jurusan Nutrisi dan Makanan Ternak, Fakultas Peternakan Universitas Brawijaya. Malang.

Van Soest, P. J. 1994. Nutritional Ecology of the Ruminant. $2^{\text {nd }}$ ed. Comstock Publishing Associates a Division of Cornell University Press. Ithaca.

Vermorel, M. 1988. Nutrition energetique. Dans: Alimentation des Bovins, Ovins et Caprins. R. Jarrige (ed). INRA-Paris. Paris. 
Wahyono, D. E. dan R. Hardianto. 2004. Pemanfaatan sumberdaya pakan lokal untuk pengembangan usaha sapi potong. Prosiding Lokakarya Nasional Sapi Potong 2004, Puslitbang Peternakan. Yogyakarta.

Widyobroto, B. P., S. Padmowijoto, dan R. Utomo. 1998. Degradasi bahan organik dan protein secara in sacco enam konsentrat sumber protein. Buletin Peternakan Edisi Khusus: 153-161.

Widyobroto, B. P., S. Padmowijoto, R. Utomo, dan Kustantinah. 1997. Pengaruh perlakuan formaldehid pada bungkil kedelai terhadap degradasi protein dalam rumen dan kecernaan undegraded protein di intestinum. Prosiding Seminar Nasional II Ilmu Nutrisi dan Makanan Ternak. Bogor.
Wina, E. and D. Abdurohman. 2005. The formation of 'ruminal bypass protein' (in vitro) by adding tannins isolated from Calliandra calothyrsus leaves or formaldehyde. Jurnal Ilmu Ternak dan Veteriner 10: 274-280.

Yusiati, L. M., Z. Bachrudin, C. Hanim, dan W. K. Ratriningtyas. 2007. Pengaruh daun ketepeng cina terhadap produksi gas methan, asam lemak volatile dan protein mikrobia pada fermentasi substrat dengan rasio hijauan dan konsentrat yang berbeda menggunakan mikroba rumen secara in vitro. Seminar Nasional Dies Natalis ke-38 Fakultas Peternakan, Universitas Gadjah Mada. Yogyakarta. 